\title{
A DNA-Based Procedure for In Planta Detection of Fusarium oxysporum f. sp. phaseoli
}

\author{
Fernando M. Alves-Santos, Brisa Ramos, M. Asunción García-Sánchez, \\ Arturo P. Eslava, and José María Díaz-Mínguez
}

Area de Genética, Centro Hispano-Luso de Investigaciones Agrarias, Universidad de Salamanca, Avda. Campo Charro s/n 37007 Salamanca, Spain.

Current address of F. M. Alves-Santos: Grupo de Leguminosas CSIC-USC, Misión Biológica de Galicia, 36080 Pontevedra, Spain.

Accepted for publication 25 October 2001.

\begin{abstract}
Alves-Santos, F. M., Ramos, B., García-Sánchez, M. A., Eslava, A. P., and Díaz-Mínguez, J. M. 2002. A DNA-based procedure for in planta detection of Fusarium oxysporum f. sp. phaseoli. Phytopathology 92:237-244.

We have characterized strains of Fusarium oxysporum from common bean fields in Spain that were nonpathogenic on common bean, as well as F. oxysporum strains (F. oxysporum f. sp. phaseoli) pathogenic to common bean by random amplified polymorphic DNA (RAPD) analysis. We identified a RAPD marker (RAPD 4.12) specific for the highly virulent pathogenic strains of the seven races of $F$. oxysporum f. sp. phaseoli.

Sequence analysis of RAPD 4.12 allowed the design of oligonucleotides that amplify a 609-bp sequence characterized amplified region (SCAR) marker (SCAR-B310A280). Under controlled environmental and greenhouse conditions, detection of the pathogen by polymerase chain reaction was $100 \%$ successful in root samples of infected but still symptomless plants and in stem samples of plants with disease severity of $\geq 4$ in the Centro Internacional de Agricultura Tropical (CIAT; Cali, Colombia) scale. The diagnostic procedure can be completed in $5 \mathrm{~h}$ and allows the detection of all known races of the pathogen in plant samples at early stages of the disease with no visible symptoms.
\end{abstract}

Fusarium oxysporum Schlechtend.:Fr. f. sp. phaseoli J.B. Kendrich \& W.C. Snyder, causal agent of Fusarium wilt of common bean (Phaseolus vulgaris L.), is one of the most important fungal pathogens of common bean and can significantly reduce the production of dry bean in several areas (1). In Spain, it is the most important disease affecting the high quality common bean cultivars grown in El Barco de Avila (Castilla y León, west-central Spain) (6). Seven races of the pathogen have been described around the world based on host differentials. The classification seems to be related to the geographic origin, because the strains from Colombia, Brazil, Italy, the United States, Greece, and Spain have been characterized as different races (22-25,30) (F. M. Alves-Santos, unpublished data). Resistance to $F$. oxysporum $\mathrm{f}$. sp. phaseoli is usually race specific $(1,22)$ and as a consequence, correct identification of the local race is essential for the choice of resistant cultivars.

Disease diagnosis and pathogen identification by traditional methods, which involve isolating the pathogen and characterizing it by inoculation tests, are labor-intensive and time-consuming. The problem is further complicated by the occurrence of saprophytic strains of $F$. oxysporum on diseased common bean plants, which are morphologically identical to F. oxysporum f. sp. phaseoli but are nonpathogenic opportunistic invaders. The use of vegetative compatibility as an indicator of pathogenicity is not possible in F. oxysporum f. sp. phaseoli, because pathogenic and nonpathogenic strains vegetatively compatible have been described (3). Diagnostic methods based on polymerase chain reaction (PCR) amplification of specific nucleic acids sequences have high analytical sensitivity to discriminate between different strains of $F$. oxysporum $(4,5,10,13,17,18)$. Also, large numbers of samples can be processed in a short time by these methods. A major drawback, however, is

Corresponding author: J. M. Díaz-Mínguez; E-mail address: josediaz@gugu.usal.es

Publication no. P-2002-0102-03R

(c) 2002 The American Phytopathological Society that the presence of amplification inhibitors in plant materials often requires the optimization of the DNA isolation procedure.

Our aim in this study was to analyze a collection of pathogenic and nonpathogenic strains of $F$. oxysporum recovered from common bean fields by random amplified polymorphic DNA (RAPD) markers, and to use this information to develop a PCR-based procedure that allows the reliable identification of $F$. oxysporum $\mathrm{f}$. sp. phaseoli in wilted common bean plants. In a previous study (3), we showed the lack of correlation between pathogenicity and several genetic features among strains of $F$. oxysporum f. sp. phaseoli. This indicates that this forma specialis is not likely a monophyletic group within $F$. oxysporum, as it has also been shown in other formae speciales (20). This view is supported by the relative abundance of physiological races that correlate with the geographic origin of the F. oxysporum f. sp. phaseoli strains. The genetic heterogeneity observed points out the need to use a highly sensitive procedure capable of detecting genetic similarities among pathogenic strains. RAPD markers are best suited to this purpose and can be readily used in the design of sequence characterized amplified region (SCAR) markers for detecting the pathogen in infected plant tissue.

\section{MATERIALS AND METHODS}

Fusarium isolates. Pathogenic and nonpathogenic strains of $F$. oxysporum used in this study are listed in Table 1 . All the strains nonpathogenic on common bean, except the Greek isolate Fo $10 \mathrm{Ph}$, and the Spanish pathogenic strains (FOP-SP), were recovered from common bean fields in the area of El Barco de Avila (Spain) and have been previously described $(2,3)$. The FOP-SP strains may be classified into two virulence groups according to the reactions on four Spanish common bean cultivars (F. M. Alves-Santos, unpublished data): weakly virulent strains and highly virulent strains, characterized by disease ratings of 5 to 7 and 9, respectively, in the Centro Internacional de Agricultura Tropical (CIAT; Cali, Colombia) scale 4 weeks after infection. Fu- 
sarium yellows severity was recorded with the CIAT scale, ranging from 1 (no external symptoms) to 9 (dead or severely infected plants with $100 \%$ of the foliage showing wilting, chlorosis, necrosis, or premature defoliation) (22). The pathogenic strains analyzed in this study represent all the currently known races of $F$. oxysporum f. sp. phaseoli described in different countries.

Media and culture conditions. All strains were grown in potato dextrose broth (PDB; Difco Laboratories, Detroit), made with $24 \mathrm{~g}$ of PDB per liter of distilled water, or potato dextrose agar (PDA; Difco), made with $39 \mathrm{~g}$ of PDA per liter of distilled water. Cultures were incubated at $22^{\circ} \mathrm{C}$ with continuous light for 3 or 4 days (liquid cultures) or up to 1 week (solid media).

Pathogenicity tests. Inoculation of cv. Blanca Riñón was carried out as previously described $(3,22)$. Plants were grown in a controlled environment chamber $\left(23\right.$ to $25^{\circ} \mathrm{C}, 60$ to $70 \%$ relative humidity) or in a greenhouse (at 19 to $30^{\circ} \mathrm{C}, 55$ to $100 \%$ relative humidity) and fertilized once a week. Fusarium yellows severity was recorded with the CIAT scale as described previously. The in planta detection assays were carried out with 10 seedlings of $\mathrm{cv}$. Blanca-Riñon inoculated with each of the representative strains of all the American $F$. oxysporum f. sp. phaseoli races: ATCC 18131 (race 1), ATCC 42145 (race 2), FOP-CL25 (race 3), and ATCC 90245 (race 4), the Spanish race (FOP-SP1 and FOP-SP5, highly virulent and weakly virulent strains, respectively, both race 6), and both Greek races (Fo $10 \mathrm{Ph}$, race 5; and F551, race 7). Seedlings were inoculated with either a strain of $F$. oxysporum nonpathogenic to bean $(\mathrm{AB} 82)$ or water as negative controls. Plants were grown in the greenhouse after inoculation for a total of 28 days. Data were collected at 0 and 1 day and 1,2,3, and 4 weeks after inoculation. For each interval of time, 10 randomly selected plants

TABLE 1. Fusarium oxysporum isolates used in this study and their characteristics

\begin{tabular}{|c|c|c|c|}
\hline Isolate & Geographic origin & Race $^{\mathrm{a}}$ & $\mathrm{VCG}^{\mathrm{b}}$ \\
\hline FOP-SP1 & La Carrera, Spain & 6 & 0167 \\
\hline FOP-SP2 & El Barco de Avila, Spain & 6 & 0167 \\
\hline FOP-SP3 & El Barco de Avila, Spain & 6 & 0168 \\
\hline $\begin{array}{l}\text { FOP-SP4, FOP-SP5, FOP-SP6, } \\
\text { FOP-SP7 }\end{array}$ & La Carrera, Spain & 6 & 0166 \\
\hline FOP-SP8 & El Barco de Avila, Spain & 6 & 0166 \\
\hline FOP-SP9 & Navalonguilla, Spain & 6 & 0166 \\
\hline $\begin{array}{l}\text { FOP-SP10, FOP-SP11, FOP- } \\
\text { SP12 }\end{array}$ & El Barco de Avila, Spain & 6 & 0169 \\
\hline ATCC 18131 & South Carolina, USA & 1 & 0161 \\
\hline ATCC 90245 & Colorado, USA & 4 & 016- \\
\hline ATCC 42145 & Rio de Janeiro, Brazil & 2 & 0162 \\
\hline Fo 5 BRA & Pernambuco, Brazil & 2 & 0162 \\
\hline Fo $28 \mathrm{COL}$ & Colombia & 3 & 0163 \\
\hline Fo $10 \mathrm{COL}$ & Colombia & 3 & 0164 \\
\hline Fo $45 \mathrm{COL}$ & Colombia & 3 & 0164 \\
\hline FOP-CL25 & Colombia & 3 & 0164 \\
\hline F9 (Fop 31) & Kavala, Greece & 5 & 0165 \\
\hline F10 (Fop 32) & Kastoria, Greece & 5 & 0165 \\
\hline F551 & Chryssoupolis, Greece & 7 & ND \\
\hline F566 & Chryssoupolis, Greece & 7 & ND \\
\hline Fo $10 \mathrm{Ph}$ & Greece & NP & ND \\
\hline $\mathrm{AB} 82, \mathrm{AB} 92$ & El Barco de Avila, Spain & NP & 0167 \\
\hline AN6, AN7 & Navalonguilla, Spain & NP & 1 \\
\hline AS2 & Solana de Avila, Spain & NP & 1 \\
\hline AB45 & El Barco de Avila, Spain & NP & 1 \\
\hline AN1, AN8 & Navalonguilla, Spain & NP & 3 \\
\hline AB26 & El Barco de Avila, Spain & NP & 3 \\
\hline $\mathrm{AB} 17, \mathrm{AB} 19, \mathrm{AB} 29$ & El Barco de Avila, Spain & NP & 4 \\
\hline $\mathrm{AB} 8, \mathrm{AB} 77$ & El Barco de Avila, Spain & NP & 5 \\
\hline AN4 & Navalonguilla, Spain & NP & 5 \\
\hline $\begin{array}{l}\mathrm{AB} 16, \mathrm{AB} 25, \mathrm{AB} 31, \mathrm{AB} 59, \\
\mathrm{AB} 70, \mathrm{AB} 73, \mathrm{AB} 86, \mathrm{AB} 106, \\
\text { AB107, AB108, AB109 }\end{array}$ & El Barco de Avila, Spain & NP & 6 \\
\hline AS3 & Solana de Avila, Spain & NP & 9 \\
\hline
\end{tabular}

a Pathogenic races determined by Woo et al. (30) and F. M. Alves-Santos (unpublished data). NP = nonpathogenic.

b Vegetative compatibilty groups are as previously determined $(2,3,28)$. were examined for (i) progression of the disease evaluated according to the CIAT scale and (ii) presence of internal discolorations. Once examined, samples of root and stem were taken from each plant and DNA was extracted from these samples to run PCR assays. The experiment was repeated a total of two times with a randomized design. The media of the CIAT ratings were calculated for all plants examined at each period of time. PCR detection of SCAR-B310A2804 in roots and stems was expressed as the percentage of plants that showed amplification of the SCAR for each type of sample.

Nucleic acids extraction. DNA from the different isolates was isolated as previously described $(3,9)$. A rapid procedure for the isolation of DNA for PCR was developed. Briefly, a patch $\left(1 \mathrm{~cm}^{2}\right)$ of mycelium was scraped from an isolate cultured on PDA and frozen in liquid nitrogen without grinding. The mycelium was resuspended in $500 \mu \mathrm{l}$ of lysis buffer $(50 \mathrm{mM}$ Tris, $\mathrm{pH} 8.0,50 \mathrm{mM}$ EDTA, $3 \%$ sodium dodecyl sulfate, $1 \% \beta$-mercaptoethanol, and $0.1 \mathrm{mg} / \mathrm{ml}$ of proteinase $\mathrm{K}$ ) at $65^{\circ} \mathrm{C}$ and incubated at $65^{\circ} \mathrm{C}$ for $40 \mathrm{~min}$. The lysate was extracted once with an equal volume of phenol and once with an equal volume of chloroform/isoamyl alcohol. Ammonium acetate was added to a final $1 \mathrm{M}$ concentration and gently mixed, and the DNA was precipitated by addition of 2 volumes of absolute ethanol and centrifugation for $15 \mathrm{~min}$ at maximum speed in a microfuge $(12,000 \times g)$. The DNA pellet was washed in $70 \%$ ethanol, dried,and resuspended in $50 \mu \mathrm{l}$ of water. Total DNA from plant samples was extracted with the EZNA Plant Miniprep Kit (Omega Biotek, Doraville, GA) following the supplier's recommendations.

PCR amplifications. Amplification of RAPD markers was performed in a thermal cycler (GeneAmp PCR System 2400; PerkinElmer, Branchburg, NJ). The primers used were decamers from the kits OPC (Operon Technologies Inc., Alameda, CA) and Genosys 70 (SIGMA-Genosys, Cambridge, UK). Forty oligonucleotides from the OPC and Genosys 70 collections were screened for their ability to produce consistent RAPD patterns. These oligonucleotides were assessed on a subset of $F$. oxysporum isolates selected for genetic diversity, geographic origin, and pathogenicity. The amplifications were performed in a total volume of $25 \mu \mathrm{l}$ containing $2 \mathrm{mM} \mathrm{MgCl} 2,200 \mu \mathrm{M}$ each deoxynucleoside triphosphate, $0.2 \mu \mathrm{M}$ each primer, $10 \mathrm{ng}$ of genomic DNA, and 1.25 units of DNA polymerase (AmpliTaq or AmpliTaq Gold; Perkin-

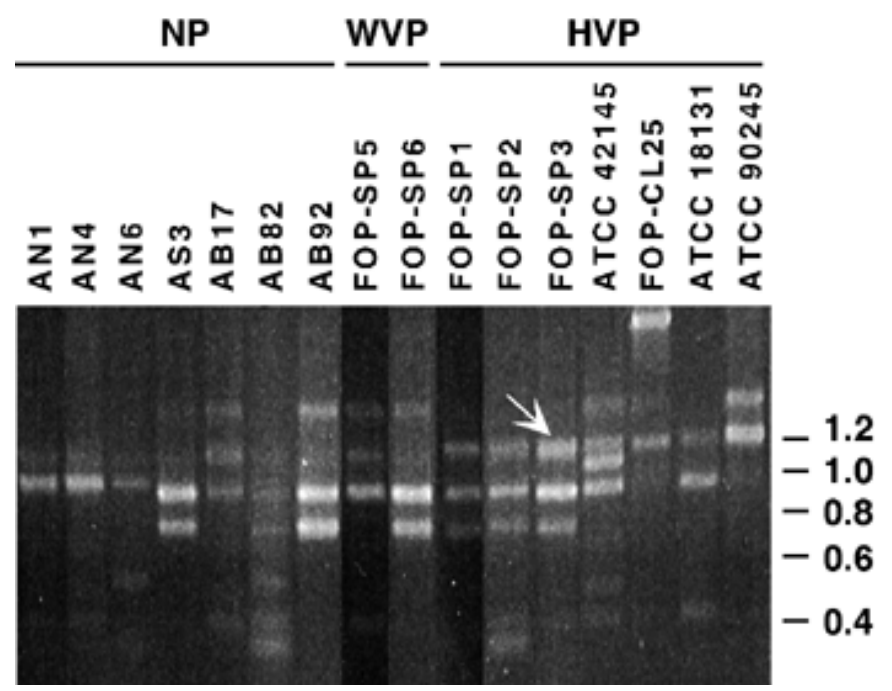

Fig. 1. Random amplified DNA polymorphisms of Fusarium oxysporum strains obtained with primer OPC18. DNA was fractionated on a $1.2 \%$ agarose gel and stained with ethidium bromide. $\mathrm{NP}=$ nonpathogenic strains; $\mathrm{WVP}=$ weakly virulent pathogens; HVP = highly virulent pathogens. The arrow indicates the band corresponding to random amplified polymorphism DNA 4.12 specific for the highly virulent strains. Sizes in kilobases of a molecular marker (100-bp ladder) are indicated on the right. 
Elmer). The amplification conditions were as follows: a denaturation step for $5 \mathrm{~min}$ at $94^{\circ} \mathrm{C}$ followed by 40 amplification cycles consisting of $1 \mathrm{~min}$ at $94^{\circ} \mathrm{C}, 1 \mathrm{~min}$ at $35^{\circ} \mathrm{C}$, and $2 \mathrm{~min}$ at $72^{\circ} \mathrm{C}$. A final extension step was performed for $10 \mathrm{~min}$ at $72^{\circ} \mathrm{C}$. The amplification of the SCAR markers was done with similar reaction mixtures, except that $2.5 \mathrm{mM} \mathrm{MgCl}_{2}, 0.6$ units of AmpliTaq polymerase, and $1 \mu \mathrm{l}$ of a 1:100 dilution of the DNA from the PCR miniprep procedure were used. The oligonucleotides used as primers for the amplification of SCAR markers were A5: 5'-TGGGTGTGATCTAGTAGGGAAACG-3'; A280: 5'-TATACCGGACGGGCGTAGTGACGATGG-3'; B285: 5'-ATCGTCACTACGCCCGTCCG-3'; and B310: 5'-CAGCCATTCATGGATGACATAACGAATTTC- ${ }^{\prime}$. The oligonucleotides used as primers for the amplification of a fragment of the pll gene (11) were PL1A: 5'-GGAAAGCACCGCCACCGTTGATGTAAGAAG-3' and PL1B: 5'-TACACTGCCATCCTCGCCCTTGCTG-3'. Amplification of a fragment of this gene was used as a control of DNA quality for PCR amplification. The amplification conditions were described previously, except that the annealing temperature was $65^{\circ} \mathrm{C}$ for primers B310-A280 and PL1A-PL1B and $56^{\circ} \mathrm{C}$ for primers A5-B285, or by the following conditions for in planta detection: a denaturation step for $5 \mathrm{~min}$ at $94^{\circ} \mathrm{C}$ followed by 25 cycles consisting of $10 \mathrm{~s}$ at $95^{\circ} \mathrm{C}, 10 \mathrm{~s}$ at $65^{\circ} \mathrm{C}$, and $20 \mathrm{~s}$ at $72^{\circ} \mathrm{C}$. Samples of the PCR products were run on $1.2 \%$ agarose gels, and the DNA was visualized under UV light after staining in a ethidium bromide solution $(0.5 \mu \mathrm{g} / \mathrm{ml})$.

Southern hybridizations. Capillary transfer of DNA to Hybond $\mathrm{N}$ membranes (Amersham, Buckinghamshire, UK) was performed as described by Sambrook et al. (26). DNA probes were labeled with Digoxigenin-11-dUTP by the PCR method using the PCR Probe Synthesis Kit (Roche Diagnostics, Mannheim, Germany). Prehybridization, hybridization, washings, and detection were performed by the chemiluminescent detection procedure with CSPD (Roche Diagnostics) according to the manufacturer's recommendations.

DNA cloning and sequencing. Amplified DNA fragments were purified from gels by the GeneClean Kit (Bio 101, Inc., Carlsbad, CA) and cloned into pGEM-T-easy vector (Promega, Madison, WI). Ligations, transformations of E. coli, and plasmid amplifications were performed following standard procedures (26). DNA sequencing was performed in an automated DNA sequencer (ABI 373A; Applied Biosystems, Foster City, CA).

Genetic similarity analysis. Similarity analyses were carried out with the RAPDistance Programs version 1.04 (J. Armstrong, A. Gibbs, R. Peakall, and G. Weiller, Australian National University, Camberra) for the analysis of patterns of RAPD fragments. Data were scored for the presence (1) or absence (0) of amplification products. Distance matrixes were obtained either using the common presence of bands (7) or both the common presence and absence of bands (28). Phenograms were constructed using the unweighted pair-group method (UPGMA) with the aid of the Phylogeny Inference Package (PHYLIP) version 3.5c (J. Felsenstein, Department of Genetics, Washington University).

\section{RESULTS}

RAPD polymorphisms. Six oligonucleotides produced polymorphic and distinguishable fragment patterns, one of which is shown in Figure 1, and were further used as primers in PCR reactions using DNA from $43 F$. oxysporum isolates (Table 1). The 19 PCR fragments selected as RAPD markers ranged from 0.7 to $2.5 \mathrm{~kb}$, appeared as bright bands after gel electrophoresis, and were consistently amplified at least in three PCR reactions with different Taq polymerases, volume reactions, and DNA from independent extractions.

To analyze the similarities between the isolates tested, we obtained the distance matrixes for the 19 RAPD markers, either by using the Dice or the Sokal and Sneath coefficients. The UPGMA

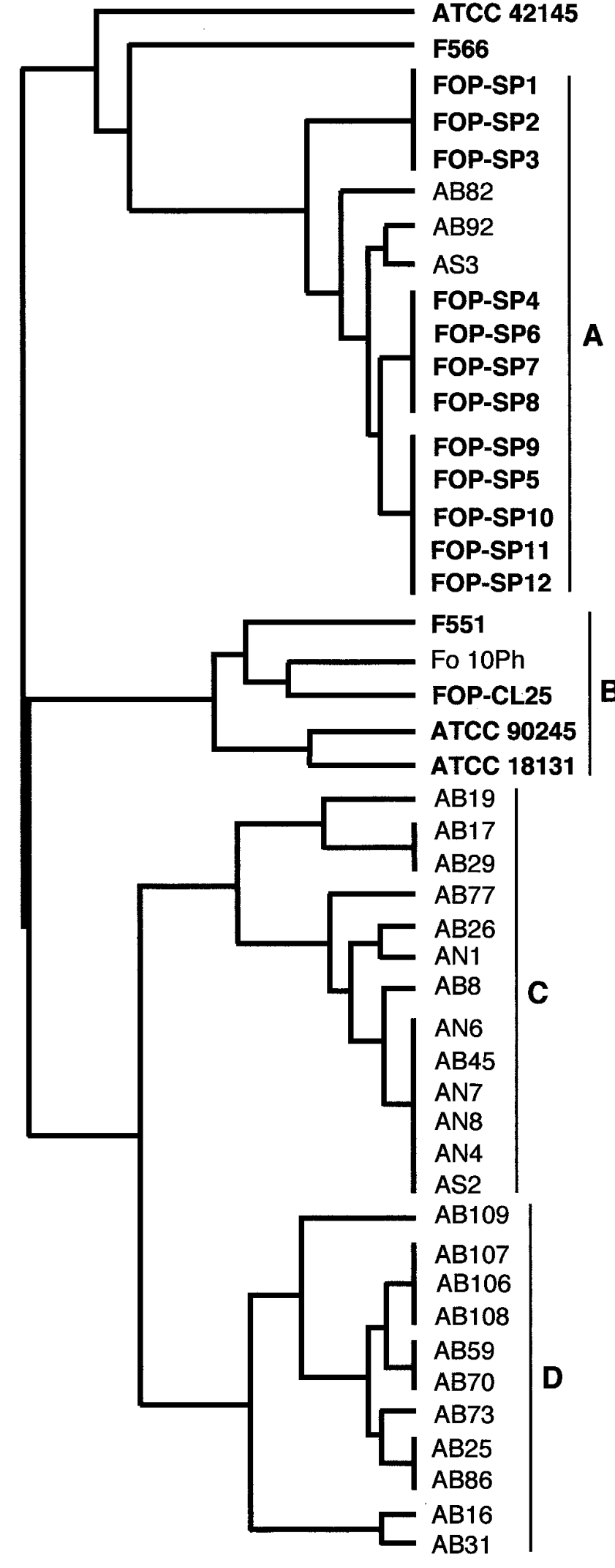

0.1

Fig. 2. Genetic similarity between Fusarium oxysporum f. sp. phaseoli strains and $F$. oxysporum strains nonpathogenic on common bean as assessed by random amplified polymorphism DNA (RAPD) analysis. The phenogram represents the unweighted pair-group method with arithmetic average tree obtained by analysis of 19 RAPD markers using the Sokal and Sneath coefficient. Pathogenic strains are in boldtype. A to $\mathbf{D}$ indicate the four clusters of strains found. 
trees obtained with both kinds of matrixes did not show significant differences. The phenogram (Fig. 2) shows four distinct clusters of strains: two clusters (Fig. 2C and D) of Spanish strains nonpathogenic on common bean, one cluster of pathogenic and nonpathogenic strains from Spain (Fig. 2A), and a fourth cluster including most of the pathogenic strains from outside Spain and a nonpathogenic isolate from Greece (Fig. 2B). The strains included in the latter cluster are more related by their difference with respect to the Spanish strains than by the similarity among themselves. The strains ATCC 42145 and F566 from Brazil and Greece, respectively, appear to be distantly related to the cluster of pathogenic and nonpathogenic strains from Spain.

Development of SCAR markers. Although none of the RAPD markers obtained correlated strictly with pathogenicity, RAPD 4.12 was amplified from all the pathogenic strains tested, regardless of the geographic origin, except the Spanish weakly virulent strains (Fig. 1). One of the bands obtained with nonpathogenic strain AB17, although similar in size, corresponds to a different fragment. This was demonstrated by cloning the AB17 fragment and sequencing both ends to show the lack of homology with RAPD 4.12 (data not shown). The DNA bands corresponding to RAPD 4.12 obtained from strains FOP-SP1 to FOP-SP3, ATCC 90245, ATCC 18131, and FOP-CL25 were cloned and sequenced. The sequences were almost identical and allowed the design of oligonucleotides A280 and B310. When PCR reactions with these two oligonucleotides as primers and DNA from the above-mentioned strains as templates were performed, one DNA fragment of 609 bp was obtained, except for strain FOP-CL25; in this case, two fragments very close in molecular size were amplified. The 609-bp DNA fragment that we named SCAR-B310A280 was sequenced, confirming that it was the expected fragment of the original RAPD 4.12 marker. To test the efficiency of oligonucleotides A280 and B310 for amplification of $F$. oxysporum f. sp. phaseoli diagnostic fragments, DNAs from a larger sample of $F$. oxysporum isolates were used as templates in PCR reactions. The results confirmed that SCAR-B310A280 was amplified from DNA of highly virulent isolates of all the known races of $F$. oxysporum f. sp. phaseoli (Fig. 3). Moreover, the collection of patho- genic strains used includes almost all the strains of $F$. oxysporum f. sp. phaseoli reported to date. The identity of the amplicons was confirmed by hybridization against the cloned SCAR-B310A280.

Analysis of RAPD 4.12. When the RAPD 4.12 was used as probe against DNA from several $F$. oxysporum f. sp. phaseoli strains and some $F$. oxysporum strains nonpathogenic on common bean, we obtained a complex hybridization pattern shown in Figure 4A. Hybridizing bands were obtained for both pathogenic and nonpathogenic strains, indicating that some regions of RAPD 4.12 were highly homologous between the two kinds of strains. To identify the region of RAPD 4.12 specific to the pathogenic strains, different probes were used in hybridization experiments against DNA from strains representing different $F$. oxysporum $\mathrm{f}$. sp. phaseoli races and some nonpathogenic strains closely related to the Spanish race 6. Hybridization with a Pst fragment corresponding to the left end of RAPD 4.12 resulted in several hybridizing bands, both in pathogenic and nonpathogenic strains (Fig. 4B). However, one of the most intense hybridizing signals specific to the pathogenic strains, corresponding to a $2-\mathrm{kb} P s t \mathrm{I}-$ PstI fragment, was missing in the hybridizing pattern obtained with the PstI fragment. This result indicated that the left region of RAPD 4.12 was homologous in pathogenic and nonpathogenic strains, whereas the right region might be specific to the pathogenic strains. By using oligonucleotides B285 and A5 as primers, we amplified the right end of RAPD 4.12 and used it as probe (Fig. 4C) against PstI-digested DNA of several strains. In this case, the 2-kb band was clearly visible in all highly virulent $F$. oxysporum f. sp. phaseoli strains, whereas no hybridizing bands could be seen in DNA from nonpathogenic or weakly virulent $F$. oxysporum strains. Thus, a 2-kb PstI-PstI genomic fragment comprising the right end of RAPD 4.12 seemed to contain the DNA region specific to the highly virulent $F$. oxysporum f. sp. phaseoli strains.

In planta detection of $\boldsymbol{F}$. oxysporum f. sp. phaseoli. Preliminary experiments with cv. Blanca-Riñón inoculated with FOP-SP1 and grown in a controlled environment chamber indicated that the SCAR-B310A280 could detect the presence of $F$. oxysporum $\mathrm{f}$. sp. phaseoli in inoculated common bean plants. The SCAR was
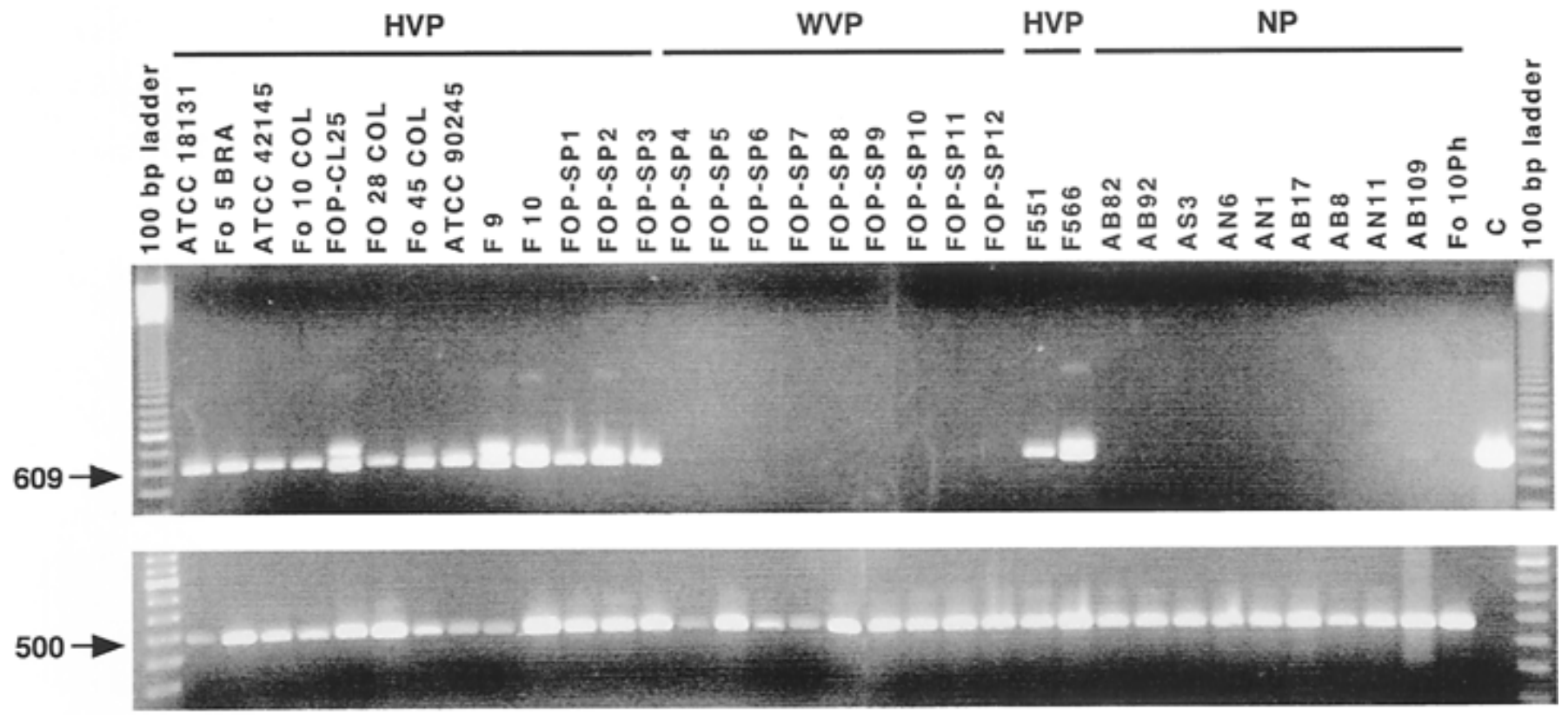

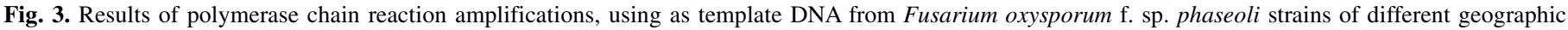

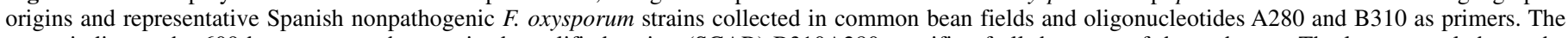

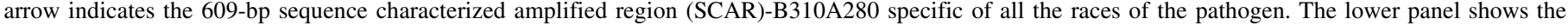

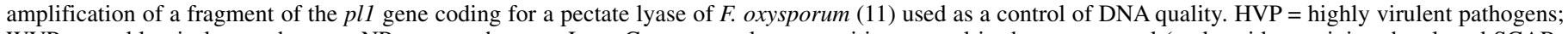

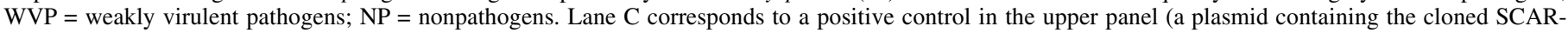
B310A280 used as template), and to a negative control in the lower panel (water instead of DNA as template). 
amplified in samples of plants showing vascular discoloration, regardless of the severity of the disease (data not shown).

To test the efficiency of the diagnostic procedure based on the SCAR-B310A280, we decided to follow the progress of Fusarium wilt on common bean plants grown under greenhouse conditions. As shown in Figure 5, amplification of the SCAR-B310A280 detected the presence of the pathogen in root samples since the first day after inoculation with almost a $100 \%$ efficiency in all the pathogenic strains tested. The presence of the pathogen in stem samples could be detected 1 week after infection. At this stage, the plants were still symptomless, but all the plants inoculated with pathogenic isolates showed some vascular discoloration. A $100 \%$ detection efficiency in stem samples was achieved for most strains 2 weeks after inoculation, when most of the plants showed CIAT ratings above 4 . The stem samples for which results are shown were collected from the crown area. Samples collected from internodal sections or from the apical meristem showed a much more variable amplification of the SCAR. No amplification was obtained from noninoculated control plants, inoculated but not transplanted seedlings (time 0 after inoculation), seedlings inoculated with the $F$. oxysporum strain nonpathogenic to common bean (AB82), and seedlings inoculated with the weakly virulent race 6 strain FOP-SP5.

The final results indicated that the DNA-based diagnosis procedure developed, based on PCR amplification of SCAR-B310A280, is capable of detecting highly virulent isolates of all the known races of $F$. oxysporum f. sp. phaseoli in $100 \%$ root samples of symptomless plants. In the case of stem samples, detection was successful in more than $50 \%$ samples of symptomless plants, and $100 \%$ samples of symptomatic plants rated $\geq 3$ in the CIAT scale.

DNA from some of the SCAR bands amplified in the detection experiments was excised from agarose gels, cloned, and both ends sequenced. Sequencing data confirmed the identity of the amplicons obtained in the detection experiments.

\section{DISCUSSION}

The first aim of this study was to characterize pathogenic and nonpathogenic isolates of $F$. oxysporum from common bean fields with RAPD markers. RAPD analysis showed that all pathogenic isolates of $F$. oxysporum f. sp. phaseoli from Spain were genetically related and they clustered together with nonpathogenic strains $\mathrm{AB} 82, \mathrm{AB} 92$, and $\mathrm{AS} 3$, whereas the pathogenic strains from America and Greece were clearly separated but did not cluster in a homogeneous group. These results confirm those obtained in our previous work (3). The FOP-SP strains and the strains AB82, $\mathrm{AB} 92$, and AS3 that share the intergenic spacer region of the nuclear ribosomal DNA (IGS-A) polymorphism and same electrophoretic karyotype (EK) pattern formed a relatively homogeneous cluster. In contrast, the $F$. oxysporum f. sp. phaseoli strains from America and Greece formed a heterogeneous cluster, in agreement with their assignment to four different IGS polymorphisms and their possession of very different EK patterns $(2,3)$. In addition, we have recently found that the FOP-SP strains belong to a race of the pathogen not previously described (F. M. Alves-Santos, unpublished data). The genetic similarities found by RAPD analy-

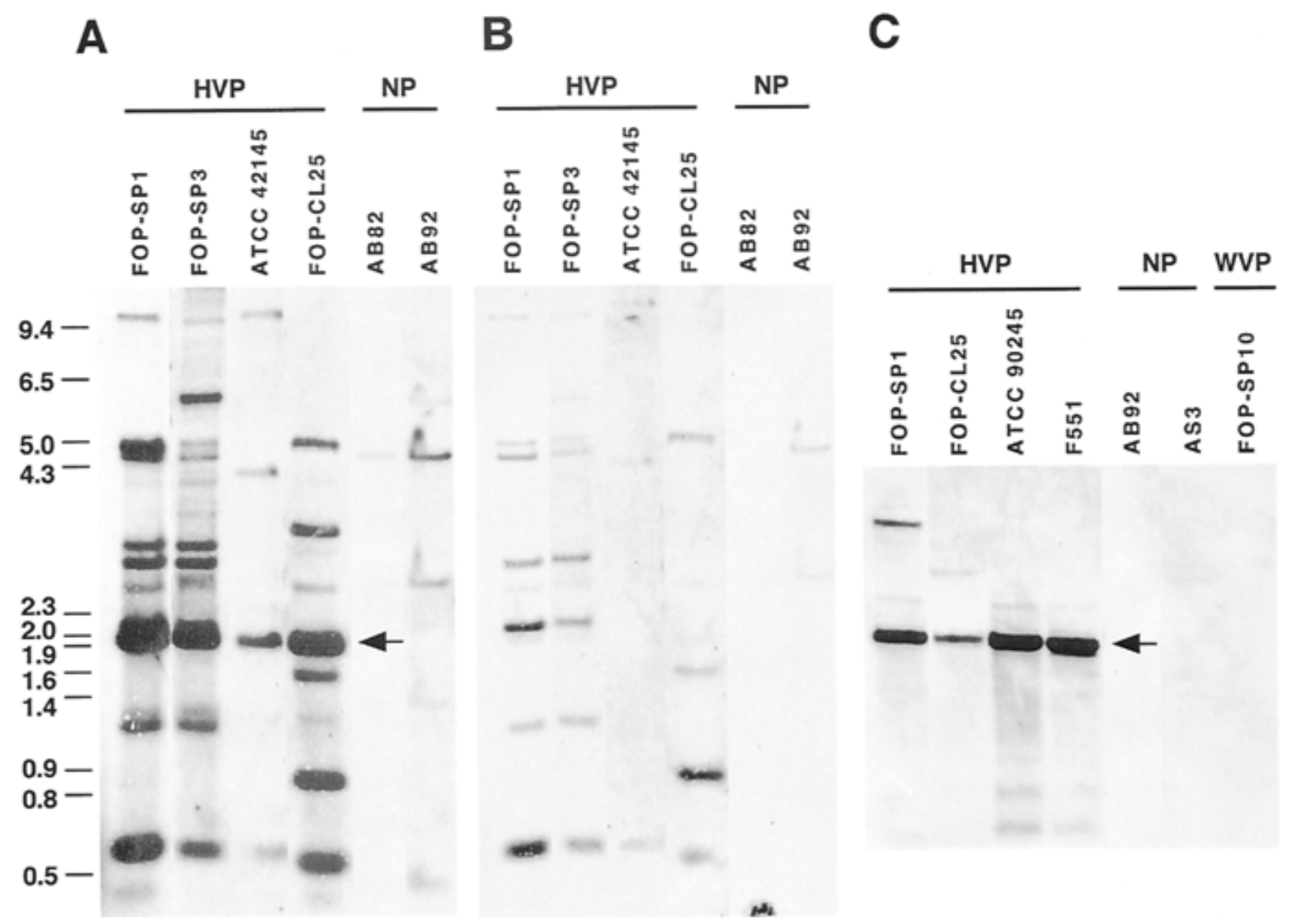

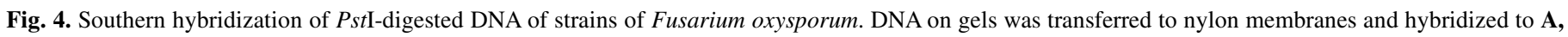

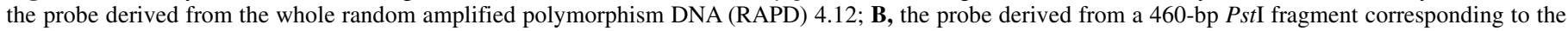

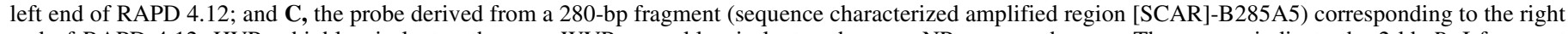

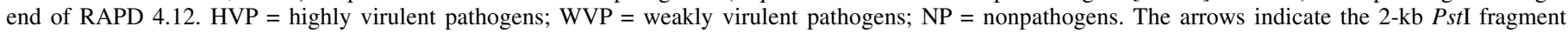
specific of the highly virulent strains. Sizes in kilobase pairs of lambda DNA digested with EcoRI and HindIII are indicated on the left. 
sis among saprophytic $F$. oxysporum strains from Spain also confirm previous results. The strains sharing vegetative compatibility group 6 and IGS-B3 polymorphism clustered together, as happens with strains that show the IGS-B1 polymorphism. The fact that all strains that are vegetatively compatible and have the same IGS polymorphism exhibit almost identical RAPD patterns confirms that groupings based on RAPD fingerprinting are congruent with previous results (3).

Despite the differences found among the FOP-SP strains and the $F$. oxysporum f. sp. phaseoli strains from other parts of the world, we were able to identify an essentially identical RAPD band (RAPD 4.12) in all the highly virulent strains. Although part

\section{ROOT}

\section{$\begin{array}{lllllll}0 & 1 & 7 & 14 & 21 & 28 & C\end{array}$}

ATCC 18131 (1)

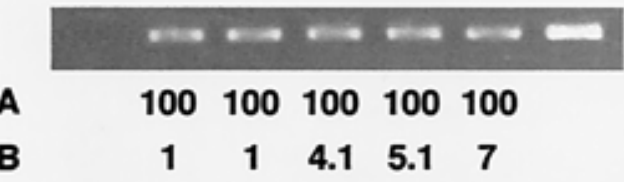

ATCC 42145 (2)

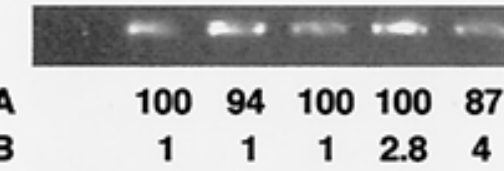

FOP-CL25 (3)

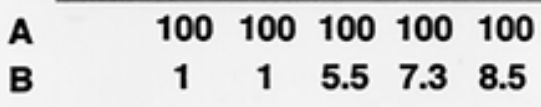

ATCC 90245 (4)

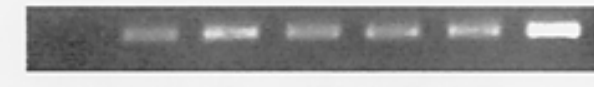
A
$\begin{array}{lllll}100 & 67 & 100 & 100 & 100\end{array}$
B
$\begin{array}{lllll}1 & 1 & 4.9 & 6.1 & 7.2\end{array}$

Fo 10Ph (5)

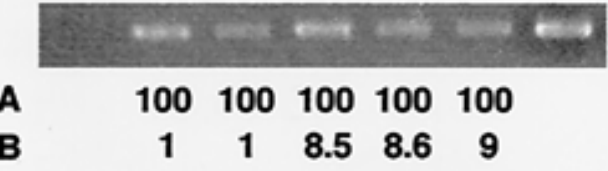

FOP-SP1 (6 HV)

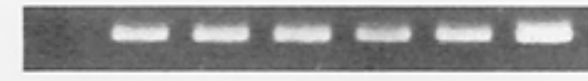

A

90100100100100

B

68.18 .5

FOP-SP5 (6 WV)

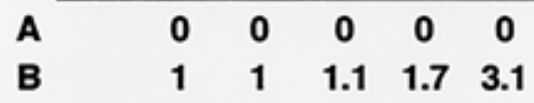

F551 (7)

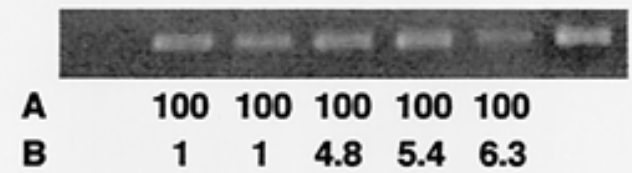

AB82 (NP)
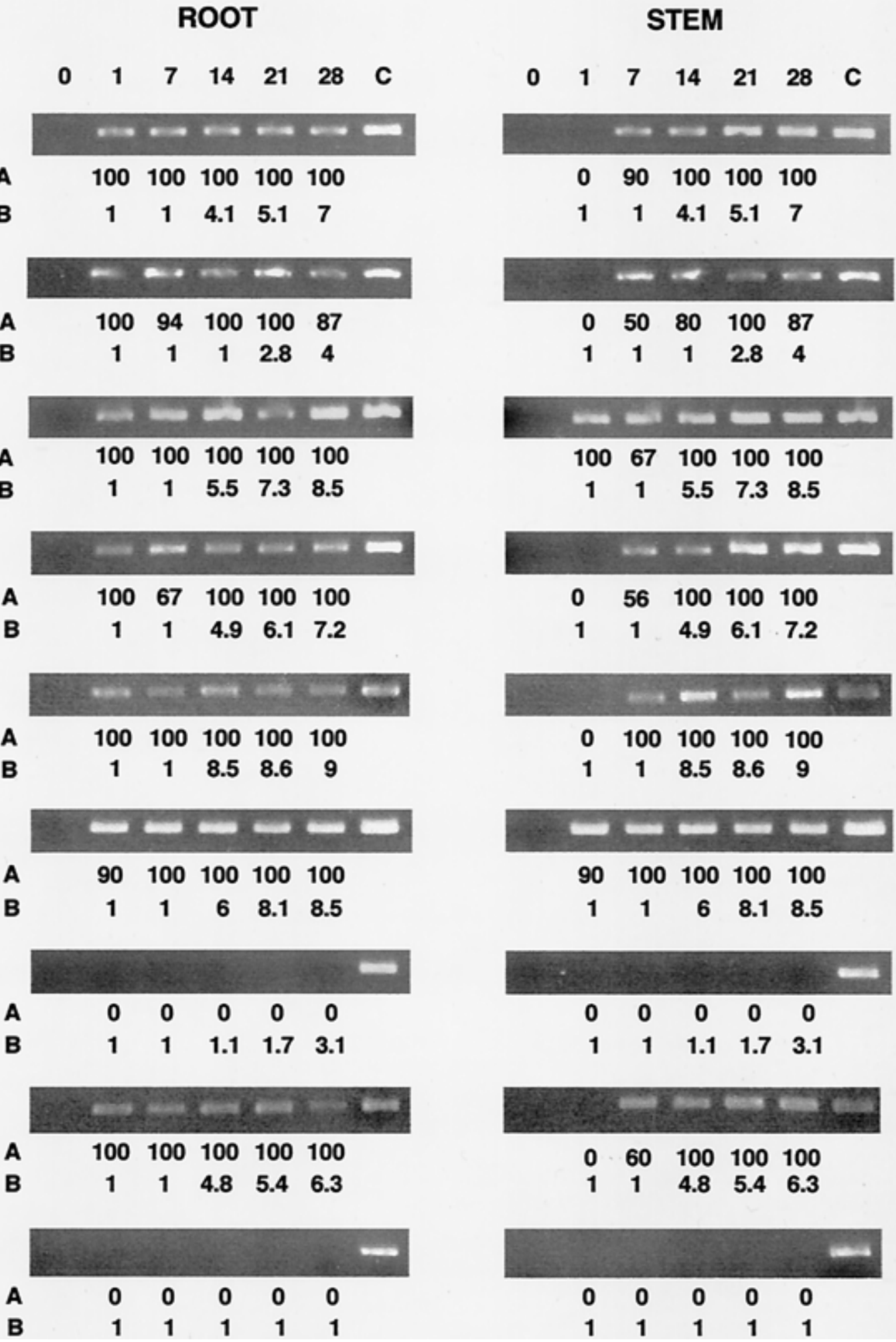

Fig. 5. Amplification of sequence characterized amplified region (SCAR)-B310A280 specific of Fusarium oxysporum f. sp. phaseoli by polymerase chain reaction, using as template DNA from root and stem tissue of infected common bean cv. Blanca-Riñon. The plants were inoculated with strains representative of the different races (race number in parenthesis; $\mathrm{HV}$ is a highly virulent strain and WV is a weakly virulent strain) and geographic origins. The numbers on top of the columns indicate the days after inoculation at which samples were taken, and C is a positive control showing the amplicon obtained from the cloned SCARB310A280. The numbers in rows labeled A are the percentage of plants sampled at each time that were positive for the amplification of SCAR-B310A280. The numbers in rows labeled $\mathbf{B}$ are the mean Centro Internacional de Agricultura Tropical (CIAT; Cali, Colombia) ratings of all the plants sampled at each time. 
of RAPD 4.12 hybridized to DNA from saprophytic $F$. oxysporum strains, we could identify a region of this RAPD marker unique to the highly virulent strains and use it to develop a SCAR marker. SCARs are useful for in planta detection of plant pathogens $(16,21,27,29)$, and even may distinguish a specific pathotype of $F$. oxysporum f. sp. ciceris (14). The two oligonucleotides, A280 and B310, developed in this study amplify SCAR-B310A280 from DNA isolated from purified fungal cultures grown in vitro and from infected common bean plants. In some cases (isolates FOPCL25, F9, F10, and F566), an additional DNA fragment slightly larger than the SCAR-B310A280 was also amplified. The high specificity of the primers used for the amplification suggests that the extra DNA fragment could be a polymorphic duplication of SCAR-B310A280. Previous reports indicate a high level of genomic duplication in some formae speciales (15) that may contribute significantly to the variation in chromosome number and genome size detected within $F$. oxysporum f. sp. phaseoli (3). However, the amplification of the extra band was observed when using DNA from fungal cultures, but was not observed when using DNA from infected plants (Fig. 3 versus Fig. 5).

The primers could detect fungal DNA in the roots of symptomless infected bean plants in very early stages, whereas the detection in stems was more dependent on the progress of the disease under greenhouse conditions. These results are in agreement with those found for other formae speciales, in which histological examination of the infected vascular tissue revealed that there were relatively few fungal structures in stem tissue compared with root tissue at 20 days after inoculation of seedlings (12). It is worthy to note that the progress of the disease was slower under greenhouse conditions than in the controlled environmental chamber (3). However, the conditions in the greenhouse are more similar to those in the field.

The use of a reliable PCR technique that allows the distinction of pathogenic from nonpathogenic $F$. oxysporum strains in infected common bean plants is of great diagnostic importance. We have reported that it is difficult to collect $F$. oxysporum f. sp. phaseoli isolates, probably because nonpathogenic, opportunistic F. oxysporum invaders outnumber the pathogenic strains once the bean plant is severely diseased (3). Pathogenic and nonpathogenic F. oxysporum isolates are morphologically indistinguishable. The identification of the pathogenic strains relies on the results of infection tests that are laborious and time consuming, because most of the fungal cultures purified from diseased bean plants are nonpathogenic. The SCAR-PCR procedure described allows for in planta detection of highly virulent $F$. oxysporum f. sp. phaseoli strains in as little as $5 \mathrm{~h}$. We do not believe that the lack of detection of weakly virulent isolates is a significant drawback. This type of isolates has only been described in Spain and belong only to one of the seven known races of the pathogen, thus accounting for a minor proportion of the pathogenic diversity described in $F$. oxysporum f. sp. phaseoli. Another important issue related to the performance of a given marker is its stability. It is apparent from numerous studies that sexual reproduction is infrequent or absent in this fungus. Therefore, it is unlikely for SCAR-B310A280 to be transferred from pathogenic to nonpathogenic strains by mating. Another source of instability is chromosomal rearrangements, which might cause the marker to be lost. Because $F$. oxysporum shows a high level of chromosomal polymorphism $(3,19,20)$, a SCAR marker might be lost due to recombination unless it is closely linked to a nondispensable gene for the organism or to a gene important to the phenotype being diagnosed (pathogenicity in this case).

We have detected fungal DNA in root and stem samples, but the detection procedure may be easily adapted to other plant structures such as seeds. Even a low transmission rate by seeds would be of great economic importance if it is the cause of disease spreading. Also, the procedure may be adapted for the detection of the pathogen in soil, as has been described for other soilborne pathogens (8). The evaluation of the level of soil infestation in plots would help to prevent Fusarium wilt by allowing efficient crop rotation procedures.

\section{ACKNOWLEDGMENTS}

This research was supported by grants 1FD97-0308-C03-01 (Ministerio de Educación y Cultura-Fondos FEDER) and PB97-1307 (Ministerio de Educación y Cultura). F. M. Alves-Santos and B. Ramos were the recipients of fellowships from the Instituto Nacional de Investigaciones Agrarias (MAPA) and M. A. García-Sánchez was the recipient of a fellowship from Caja Rural de Salamanca. We thank G. Mahuku and K. Elena for providing fungal isolates and $\mathrm{M}$. Perlin for critical reading of the manuscript.

\section{LITERATURE CITED}

1. Abawi, G. S., and Pastor-Corrales, M. A. 1990. Root rots of beans in Latin America and Africa: Diagnosis, research methodologies and management strategies. Centro Internacional de Agricultura Tropical (CIAT), Cali, Colombia.

2. Alves-Santos, F. M. 1999. La fusariosis de la judía en Castilla y León: Caracterización y diagnóstico molecular de los patógenos. Tesis Doctoral. Universidad de Salamanca.

3. Alves-Santos, F. M., Benito, E. P., Eslava, A. P., and Díaz-Mínguez, J. M. 1999. Genetic diversity of Fusarium oxysporum strains from common bean fields in Spain. Appl. Environ. Microbiol. 65:3335-3340.

4. Assigbetse, K. B., Fernández, D., Dubois, M. P., and Geiger, J.-P. 1994. Differentiation of Fusarium oxysporum $\mathrm{f}$. sp. vasinfectum races on cotton by random amplified polymorphic DNA (RAPD) analysis. Phytopathology 84:622-626.

5. Bentley, S., Pegg, K. G., and Dale, J. L. 1995. Genetic variation among a worldwide collection of isolates of Fusarium oxysporum f. sp. cubense analyzed by RAPD-PCR fingerprinting. Mycol. Res. 99:1378-1384.

6. Díaz-Mínguez, J. M., Alves-Santos, F. M., Benito, E. P., and Eslava, A. P. 1996. Fusarium wilt of common bean in the Castilla y León region of Spain. Plant Dis. 80:600.

7. Dice, R. L. 1945. Measures of the amount of ecologic association between species. Ecology 26:297-302.

8. García-Pedrajas, M. D., Bainbridge, B. W., Heale, J. B., Pérez, A. E., and Jiménez-Díaz, R. M. 1999. A simple PCR-based method for the detection of the chickpea-wilt pathogen Fusarium oxysporum f. sp. ciceris in artificial and natural soils. Eur. J. Plant Pathol. 105:251-259.

9. Graham, G. C., Mayers, P., and Henry, R. J. 1994. A Simplified method for the preparation of fungal genomic DNA for PCR and RAPD analysis. Biotechniques 16:48-50.

10. Grajal-Martín, M. J., Simon, C. J., and Muehlbauer, F. J. 1993. Use of random amplified polymorphic DNA (RAPD) to characterize race 2 of Fusarium oxysporum f. sp. pisi. Phytopathology 83:612-615.

11. Huertas-González, M. D., Ruiz-Roldán, M. C., García-Maceira, F. I., Roncero, M. I. G., and Di Pietro, A. 1999. Cloning and characterization of pll encoding an in planta-secreted pectate lyase of Fusarium oxysporum. Curr. Genet. 35:36-40.

12. Jiménez-Díaz, R. M., Basallote-Ureba, M. J., and Rapoport, H. 1989. Colonization and pathogenesis in chickpea infected by races of Fusarium oxysporum f. sp. ciceris. Pages 113-121 in: Vascular Wilt Diseases of Plants. E. C. Tjamos and C. H. Beckman, eds. Springer-Verlag, Heidelberg.

13. Kelly, A., Alcalá-Jiménez, A. R., Bainbridge, B. W., Heale, J. B., PérezArtés, E., and Jiménez-Díaz, R. M. 1994. Use of genetic fingerprinting and random amplified polymorphic DNA to characterize pathotypes of Fusarium oxysporum f. sp. ciceris infecting chickpea. Phytopathology 84:1293-1298.

14. Kelly, A. G., Bainbridge, B. W., Heale, J. B., Pérez-Artés, E., and Jiménez-Díaz, R. M. 1998. In-planta-polymerase-chain-reaction detection of the wilt-inducing pathotype of Fusarium oxysporum f. sp. ciceris in chickpea (Cicer arietinum L.). Physiol. Mol. Plant Pathol. 52:397409.

15. Kistler, H. C., Benny, U., Boehm, E. W. A., and Katan, T. 1995. Genetic duplication in Fusarium oxysporum. Curr. Genet. 28:173-176.

16. McDermott, J. M., Brändle, U., Dutly, F., Haemmerli, U. A., Keller, S., Müller, K. E., and Wolfe, M. S. 1994. Genetic variation in powdery mildew of barley: Development of RAPD, SCAR and VNTR markers. Phytopathology 84:1316-1321.

17. Migheli, Q., Berio, T., Gullino, M. L., and Garibaldi, A. 1995. Electrophoretic karyotype variation among pathotypes of Fusarium oxysporum f. sp. dianthi. Plant Pathol. 44:308-315.

18. Migheli, Q., Briatore, E., and Garibaldi, A. 1998. Use of random am- 
plified polymorphic DNA (RAPD) to identify races $1,2,4$ and 8 of $F u$ sarium oxysporum f. sp. dianthi in Italy. Eur. J. Plant Pathol. 104:49-57.

19. Mills, D., and McCluskey, K. 1990. Electrophoretic karyotypes of fungi: The new cytology. Mol. Plant-Microbe Interact. 3:351-357.

20. O’Donnell, K., Kistler, H. C., Cigelnik, E., and Ploetz, R. C. 1998. Multiple evolutionary origins of the fungus causing Panama disease of banana: Concordant evidence from nuclear and mitochondrial gene genealogies. Proc. Natl. Acad. Sci. USA 95:2044-2049.

21. Paran, I., and Michelmore, R. W. 1993. Development of reliable PCRbased markers linked to downy mildew resistance genes in lettuce. Theor. Appl. Genet. 85:985-993.

22. Pastor-Corrales, M. A., and Abawi, G. S. 1987. Reactions of selected bean germ plasms to infection by Fusarium oxysporum f. sp. phaseoli. Plant Dis. 71:990-993.

23. Ribeiro, R. d. L. D., and Hagedorn, D. J. 1979. Screening for resistance to and pathogenic specialization of Fusarium oxysporum f. sp. phaseoli, the causal agent of bean yellows. Phytopathology 69:272-276.

24. Ribeiro, R. d. L. D., and Hagedorn, D. J. 1979. Inheritance and nature of resistance in beans to Fusarium oxysporum f. sp. phaseoli. Phytopathology 69:859-861.
25. Salgado, M. O., and Schwartz, H. F. 1993. Physiological specialization and effects of inoculum concentration of Fusarium oxysporum f. sp. phaseoli on common beans. Plant Dis. 77:492-496.

26. Sambrook, J., Fritsch, E. F., and Maniatis, T. 1989. Molecular Cloning: A Laboratory Manual. 2nd ed. Cold Spring Harbor Laboratory, Cold Spring Harbor, New York.

27. Schilling, A. G., Möller, E. M., and Geiger, H. H. 1996. Polymerase chain detection-based assays for species-specific detection of Fusarium culmorum, F. graminearum, and F. avenaceum. Phytopathology 86:515522.

28. Sokal, R. R., Sneath, P. H. A. 1963. Principles of Numerical Taxonomy. W. H. Freeman \& Co., New York.

29. Wiglesworth, M. D., Nesmith, W. C., Schardl, C. L., Li, D., and Siegel, M. R. 1994. Use of specific repetitive sequences in Peronospora tabacina for the early detection of the tobacco blue mold pathogen. Phytopathology 84:425-430.

30. Woo, S. L., Zoina, A., Del Sorbo, G., Lorito, M., Nanni, B., Scala, F., and Noviello, C. 1996. Characterization of Fusarium oxysporum f. sp. phaseoli by pathogenic races, VCGs, RFLPs, and RAPD. Phytopathology 86:966-973. 